\title{
JURNAL SAINS DAN TEKNOLOGI LABORATORIUM MEDIK
}

\author{
ISSN : 2621-7708 (media online)
}

\section{UJI LISIS TELUR Ascaris lumbricoides SETELAH PEMBERIAN GETAH PEPAYA (Carica papaya)}

\author{
Darmadi ${ }^{1}$, Khairunnisa, $\mathrm{D}^{2}$, \\ ${ }^{1}$ Univrab (Analis Kesehatann, FKIK, Universitas Abdurrab) \\ (Jalan Rawo Bening Sidomulyo Barat, Kota Pekanbaru, Negara Indonesia, 28292) \\ darmadi@univrab.ac.id \\ ${ }^{2}$ Univrab (Analis Kesehatann, FKIK, Universitas Abdurrab) \\ (JalanTj Datuk Gg SD 069 Kota Pekanbaru, Negara Indonesia,28292)
}

\begin{abstract}
ABSTRAK
Penyakit kecacingan tergolong penyakit neglected disease yaitu infeksi yang kurang diperhatikan dan penyakitnya bersifat kronis tanpa menimbulkan gejala klinis yang jelas. Dampak yang ditimbulkannya baru terlihat dalam waktu yang lama seperti kekurangan gizi, gangguan tumbuh kembang dan gangguan kecerdasan pada anak. Berbagai upaya yang telah dilakukan untuk mengeliminasi adanya cacing di dalam tubuh, mulai dari penggunaan obat sintetik hingga penggunaan obat alami. Salah satu obat alami yang dapat dijadikan sebagai antihelmintik adalah getah pepaya (Carica papaya).Tujuan dari penelitian ini adalah untuk menentukan konsentrasi getah pepaya (Carica papaya) yang efektif terhadap lisisnya telur Ascaris lumbricoides.Metode yang digunakan dalam penelitian ini eksperimen laboratorium secara in vitro. Hasil yang di dapatkan dari penelitian adalah getah papaya pada konsentrasi 5\% dapat menyebabkan lapisan albumin telur mengalami perubahan (menyerupai fertilized decorticated) pada waktu selama 60 menit, sedangkan getah papaya konsentrasi 1\%-4\% tidak mengalami perubahan yang signifikan. Kesimpulan dari penelitian ini adalah bahwa getah pepaya pada konsentrasi 5\% tidak menimbulkan lisis tetapi lapisan albumin dari telur mengalami perubahan menyerupai fertilized decorticated.
\end{abstract}

Kata kunci : lisis, Ascaris lumbricoides, Getah Pepaya.

\begin{abstract}
Worm disease is classified as neglected disease, which is an infection that is not considered and the disease is chronic without causing clear clinical symptoms and its effects are only seen in a long time such as malnutrition, growth and development disorders and intelligence disorders in children. Various attempts have been made to eliminate the presence of worms in the body, ranging from the use of synthetic drugs to the use of natural medicines. One natural remedy that can be used as an antihelmintic is papaya sap (Carica papaya). The purpose of this study was to determine the concentration of papaya sap (Carica papaya) which was effective against the lysis of Ascaris lumbricoides eggs. The method used in this study is in vitro laboratory experiments. The results obtained from the study are papaya sap at a concentration of 5\% can cause the albumin layer of eggs to experience changes (similar to fertilized decorticated) at a time of 60 minutes, while papaya sap concentration of $1 \%-4 \%$ did not experience significant changes. The conclusion of this study is that papaya sap at a concentration of 5\% does not cause lysis but the albumin layer of the egg undergoes changes resembling fertilized decorticated.
\end{abstract}

Keywords : lysis, Ascaris lumbricoides, Papaya sap 


\section{PENDAHULUAN}

Indonesia merupakan negara tropis yang masih banyak ditemukan penyakit infeksi terutama yang berkaitan dengan kondisi sanitasi lingkungan yang belum baik.Salah satu infeksi yang menjadi masalah kesehatan oleh masyarakat Indonesia yaitu infeksi cacing.Indonesia juga adalah negara dengan keadaan mutu sanitasi masyarakat yang masih rendah yang sangat mendukung untuk terjadinya infeksi dan penularan cacing.Penyakit kecacingan adalah penyakit rakyat yang pada umumnya infeksidapat terjadi secara bersamaan oleh beberapa jenis cacing sekaligus. Salah satu penyakit kecacingan adalah penyakit infeksi cacing usus yang ditularkan melalui tanah yang banyakdijumpai pada anak usia sekolah dasar yang masih sering kontak dengan tanah (Safar, 2009).

Penyakit kecacingan tergolong penyakit neglected disease yaitu infeksi yang kurang diperhatikan dan penyakitnya bersifat kronis tanpa menimbulkan gejala klinis yang jelas dan dampak yang ditimbulkannya baru terlihat dalam waktu yang lama seperti kekurangan gizi, gangguan tumbuh kembang dan gangguan kecerdasan pada anak (Soedarto, 2016). Cacing yang tergolong dalam kelompok Soil Transmitted Helminths $(\mathrm{STH})$ adalah cacing yang dalam menyelesaikan siklus hidupnya memerlukan tanah yang sesuai untuk berkembang menjadi bentuk infektif. Empat jenis STH yang paling sering ditemukan adalah cacing gelang (Ascaris lumbricoides), cacing cambuk (Trichuris trichiura), dan cacing tambang (Necator americanus dan Ancylostoma duodenale)(Susanto dkk, 2008).

Tingginya angka prevalensi kecacingan menjadi permasalahan yang memprihatinkan.Oleh karena itu perlu dilakukan tindakan preventif supaya perkembangan telur dalam tubuh tidak terjadi.Infeksi cacing dapat diatasi dengan pemberian obat berjenis antelmintik.Namun penggunaan obat yang mengandung bahan kimia dalam jangka waktu yang lama memiliki efek tidak baik bagi tubuh, sehingga dapat menyebabkan terjadinya resistensi pada tubuh. Oleh sebab itu masyarakat sudah banyak mengkosumsi obat herbal, Indonesia adalah satu Negara yang memiliki jenis tanaman obat tradisional yang beraneka ragam (Suriptiastuti, 2006).

Pepaya merupakan salah satu tanaman obat yang memiliki daya antihelmintik yang tersedia dalam jumlah relatif cukup banyak serta mudah ditemukan di setiap daerah. Tanaman pepaya banyak ditanam masyarakat, baik di daerah tropis maupun subtropis, di daerah - daerah basah dan kering, atau di daerah - daerah dataran dan pegunungan (Suryatinah dkk, 2013). Pepaya mengandung enzim papain yang sering ditemukan pada akar, batang, daun, getah, buah dan biji. Selain enzim papain papaya juga mengandung senyawa alkaloid, carpain, karpasemin dan glikosida benzil isotiosianat (Andiarsa, 2014).

Penelitian sebelumnya yang telah dilakukan oleh Andiarsa (2014) menyebutkan bahwa hasil biji pepaya muda dan biji pepaya masak (Carica papaya) mempunyai daya antelmintik terhadap cacing Ascaris suum secara in vitro walaupun piperasin sitrat $0,2 \%$ dan biji pepaya masak kurang efektif. Biji pepaya muda mempunyai aktivitas antelmintik yang lebih baik dari pada biji pepaya masak. $\mathrm{LC}_{50}$ dan $\mathrm{LT}_{50}$ biji papaya muda (Carica papaya) yaitu sebesar $14,36167 \%$ dan $18,97687 \%$.

Penelitian yang dilakukan Suryatinah dkk (2013) melakukan uji pengaruh sistein terhadap aktivitas proteolitik papain kasar pada kematian cacing Ascaris galli secara in vitromenunjukkan kematian cacing bervariasi menurut jenis papain kasar yang digunakan pada setiap waktunya. Papain kasar B (penambahan sistein) jelas memberikan efek kematian lebih cepat dibandingkan dengan papain kasar A (tanpa penambahan sistein). Penambahan sistein pada aktivitas proteolitik papain kasar memberikan pengaruh lebih sehingga penambahan sistein memiliki persentase rata - rata kematian cacing yang lebih baik dibandingkan tanpa penambahan sistein. 
Berdasarkan latar belakang yang telah diuraikan di atas, maka peneliti tertarik melakukan penelitian tentang uji lisis telur Ascaris lumbricoides penyebab kotaminan cacing setelah pemberian getah pepaya (Carica papaya).

\section{METODOLOGI}

Metode yang digunakan dalam penelitian ini adalah eksperimental laboratorium secara invitro. Penelitian dilakukan untuk mengetahui terjadinya lisis pada telur Ascaris lumbricoides penyebab kontaminan cacing setelah pemberian getah papaya (Carica papaya) dengan variasi konsentrasi 1\%, 2\%, 3\%, 4\%, dan 5\%.

\section{Prosedur Kerja}

\section{Pengambilan getah dari buah pepaya}

Sebanyak 5 buah pepaya muda dilakukan penyadapan untuk memperoleh getah pada buah.Satu buah pepaya dapat dilakukan 5 kali penyadapan. Penyadapan dilakukan dengan cara menggoreskan buah tersebut menggunakan pisau. Getah yang keluar dari buah segera ditampung ke dalam wadah (Widiastuti dkk, 2015).

\section{Pembuatan serbuk getah pepaya}

Hasil penyedapan getah segar dicampurkan dengan larutan etanol 80\% sebanyak 3 kali jumlah getah, lalu diaduk hingga merata dengan alat pengaduk dan diendapkan. Setelah terbentuk endapan putih dibagian dasar campuran, cairan dipisahkan dari endapan.Selanjutnya endapan di masukan ke dalam cawan porselen.Cawan tersebut dimasukan ke dalam oven pada suhu $50^{\circ} \mathrm{C}$ selama 8 jam.setelah endapan getah kering seperti serbuk kasar diambil lalu dihaluskan hingga berbentuk bubuk ( Suryatinah dkk, 2013).

\section{Pembuatan konsentrasi getah pepaya}

Disediakan lima botol vial. Pada botol I dilarutkan 0,1 gram serbuk getah pepaya dalam $10 \mathrm{~mL} \mathrm{NaCl}$ fisiologis, pada botol II dilarutkan 0,2 gram serbuk getah pepaya dalam $10 \mathrm{mLNaCl}$ fisiologis. Pada botol III dilarutkan 0,3 gram serbuk getah pepaya dalam $10 \mathrm{mLNaCl}$ fisiologis. Pada botol IV dilarutkan 0,4 gram serbuk getah pepaya dalam $10 \mathrm{mLNaCl}$ fisiologis. Terakhir pada botol $\mathrm{V}$ dilarutkan 0,5 gram serbuk getah pepaya dalam $10 \mathrm{mLNaCl}$ fisiologis ( Widiastuti dkk, 2015).

\section{Identifikasi telur Ascaris lumbricoides}

Persiapkan kaca objek yang bersih dan bebas lemak, diteteskan 1-2 tetes eosin 2\% di bagian tengah kaca objek glass.Kemudian dengan menggunakan bagian ujung lidi, feses diambil dan diratakan pada kaca objek yang telah ditetesi eosin $2 \%$ dan dihomogenkan.Perhatikan kembali jika terdapat bahan yang kasar maka dikeluarkan dengan menggunakan lidi. Kemudian tutup dengan kaca penutup, pastikan agar sediaan tipis dengan cara menekan kaca penutup lalu diperiksa di bawah mikroskop dengan pembesaran 100x (Idris dan fusvita, 2017).

5.

PengumpulantelurAscaris lumbricodesdenganmetode sedimentasi

Siapkan alat dan bahan yang bersih dan steril, masukan feses positif telur Ascaris lumbricoides seujung lidi ke dalam tabung reaksi dan masukan larutan $\mathrm{NaCl} 0,9 \%$ ke dalam tabung sebanyak $2,5 \mathrm{~mL}$, feses dihancurkan menggunakan batang pengaduk.Kemudian tabung reaksi di isi sampai $3 / 4$ dengan larutan $\mathrm{NaCl} 0,9 \%$ dan homogenkan.Kemudian di sentrifuge dengan kecepatan $3000 \mathrm{rpm}$ selama 3 menit, kemudian sedimen yang didapat dilakukan pengujian dengan getah pepaya (Regina dkk, 2018).

6.

\section{PegujianlisistelurAscarislumbricoidesterha dap getah pepaya}

Pemeriksaan ini menggunakan konsentrasi yang bertingkat mulai dari 1\%, 2\%, 3\%, 4\% dan 5\%, terlebih dahulu siapkan 5 objek glass dan diberi label sesuai konsentrasi yang diperiksa. Teteskan 1 tetes endapan yang didapat dari hasil pengumpulan telur Ascaris lumbricoidesdengan metode sedimentasi. Kemudian ditambahkan 1 tetes getah pepaya konsentrasi $1 \%$ pada kaca objek I, 1 tetes 
getah pepaya konsentrasi $2 \%$ pada kaca objek II, 1 tetes getah pepaya konsentrasi $3 \%$ pada kaca objek III, 1 tetes getah pepaya konsentrasi $4 \%$ pada kaca objek IV, dan 1 tetes getah pepaya konsentrasi $5 \%$ pada kaca objek V. Amati di bawah mikroskop dengan lensa pembesaran 100x. Terjadi lisis pada telur cacing Ascaris lumbricoides dengan terlihat rusaknya komponen sel telur dengan pemberian getah pepaya (Carica papaya) pada konsentrasi tertentu (Kalma, 2018).

\section{HASIL DAN PEMBAHASAN}

\section{Serbuk getah papaya (Carica papaya)}

Getah pepaya yang diperoleh dari penorehan 5 buah pepaya muda kemudian dikeringkan menggunakan oven.Setelah benar-benar kering getah pepaya dihaluskan hingga menjadi serbuk dengan ciri-ciri berwarna putih kecoklatan. Serbuk getah pepaya (Carica papaya) diencerkan dengan $\mathrm{NaCl} 0,9 \%$ untuk mendapatkan konsentrasi $1 \%, 2 \%, 3 \%, 4 \%$, dan $5 \%$.

\section{Hasil identifikasi telur Ascaris lumbricoides dari sampel feses}

Sampel yang digunakan dalam penelitian ini adalah suspensi telur Ascaris lumbricoides yang diperoleh dari feses segar. Kemudian sampel tersebut dibawa ke Laboratorium Parasitologi Universitas Abdurrab Pekanbaru untuk dilakukan pemeriksaan mikroskopis telur cacing usus. Dari hasil pemeriksaan ditemukan telur cacing dengan bentuk lonjong dengan 3 lapisan yang permukaannya bergerigi. Berdasarkan ciri-ciri tersebut maka sampel dinyatakan positif mengandung telur Ascaris lumbricoides.

3. Perlakuan uji lisis telur Ascaris lumbricoides oleh konsentrasi getah pepaya (Carica papaya)

Pengujian getah pepaya (Carica papaya) terhadap telur Ascaris lumbricoides dilakukan dengan cara membuat sediaan yang terdiri dari endapan hasil sedimentasi ditambahkan getah pepaya konsentrasi $1 \%$, $2 \%, 3 \%, 4 \%$, dan $5 \%$ secara berurutan pada masing-masing kaca objek, kemudian dihomogenkan ditutup dengan kaca penutup. Sediaan diperiksa di bawah mikroskop untuk melihat perubahan pada komponen telur Ascaris lumbricoides setelah diberi getah pepaya (Carica papaya) dengan konsentrasi yang berbeda. Pengamatan pada setiap preparat dilakukan setiap 15 menit sekali sampai 60 menit.

Tabel 3.1 Hasil uji Lisis Telur Ascaris lumbricoides Setelah Pemberian Getah Pepaya (Carica papaya).

Berdasarkan hasil penelitian yang telah dilakukan bahwa getah pepaya (Carica papaya) mampu merubah morfologi telur Ascaris lumbricoides konsentrasi 5\% pada waktu 30 sampai 60 menit. Pada 30 menit warna pada telur cacing memudar dan lapisan albumin mulai terkikis, sementara pada waktu 45 menit warna pada telur memudar dan lapisan albumin pada telur terkikis.Pada waktu 60 menit warna telur memudar dan lapisan albumin mulai hilang.

Menurut penelitian Sonda, dkk (2018) dengan judul vermisidal dan ovasidal ekstrak biji pepaya muda terhadap Ascaridia galli secara In vitro mengatakan bahwa uji vermisidal $\mathrm{LC}_{100}$ dan $\mathrm{LT}_{100}$ dari ekstrak biji pepaya muda didapatkan LC $_{100}$ ekstrak pepaya muda adalah $0,371 \%$ dan $\mathrm{LT}_{100}$ 34,614 jam. Untuk uji ovisidal kontak langsung dan kontak tidak langsung didapatkan bahwa ekstrak biji pepaya muda berpengaruh sangat nyata $(\mathrm{P}<0,05)$ terhadap daya embrio cacing Ascaridia galli.

Getah pepaya (Carica papaya) merupakan tanaman yang dapat digunakan sebagai obat herbal.Getah pepaya mempunyai sifat-sifat yang menguntungkan untuk perawatan obat herbal yang mengandung senyawa kimia alkaloid, flavonoid, betakaroten, betacryptoxanthin, tanin, saponin, lutein.Pepaya juga memliki enzim yang dapat memecah protein menjadi arginin yang disebut enzim papain. Kandungan utama yaitu enzim papain yang berfungsi sebagai antelmintik (Yahya, 2012) 
Kandungan papain menunjukkan aktivitas proteolitik yang dapat memecah dan mengurai protein.Getah pepaya mengandung enzim papain yang dapat mengurai parasit sehingga dapat dijadikan antelmintik. Mekanisme sistein proteinase pepaya yaitu enzim papain menjadikan protein pada kutikel sebagai target lalu melemahkan kutikel dan sebabkan ruptur sehingga terjadi pelepasan jaringan internal yang memicu kematian cacing atau dengan menyebabkan paralisis pada cacing yang berujung kematian (Suryatinah dkk,2013).

Dari hasil penelitian dapat dilihat pada gambar dengan konsentrasi 5\% terjadi perubahan warna pada telur Ascaris lumbricoidesdan semakin lama waktu yang digunakan pada telur maka semakin memudar warna telur tersebut.Hal ini dapat dibandingkan pada konsentrasi $1-4 \%$ dengan masing - masing waktu uji.

Mekanisme obat cacing Albendazole memiliki daya ovisidal yang kuat terhadap cacing dengan cara merusak struktur telur (deformasi). Efek ovicidal dari methylcarbamates benzimedazole pada golongan cacing nematoda tidak hanya afinitas $\beta$-tubulin saja, tetapi juga kemampuannya untuk menembus kulit telur dan menumpuk di dalam telur.Penghambatan telur cacing menetas juga tergantung pada sifat hidrofobik obat, di mana peningkatan aktivitas berkorelasi dengan daya larut lemak.Menurut hasil penelitian diatas, dapat diketahui bahwa getah pepaya (Carica papaya) yang mengandung enzim papain yang bersifat antelmintik mampu untuk memecah protein sehingga dapat merubah morfologi telur dan mengikis lapisan albumin telur Ascaris lumbricoides.

\section{KESIMPULAN}

Berdasarkan penelitian yang dilakukan didapatkan bahwa getah papaya (Carica papaya) pada konsentrasi 1 sampai $4 \%$ tidak dapat melisiskan telur Ascaris lumbricoides.sedangkan Pada konsentrasi 5\% mampu merubah morfologi telur Ascaris lumbricoides dalam waktu 60 menit.

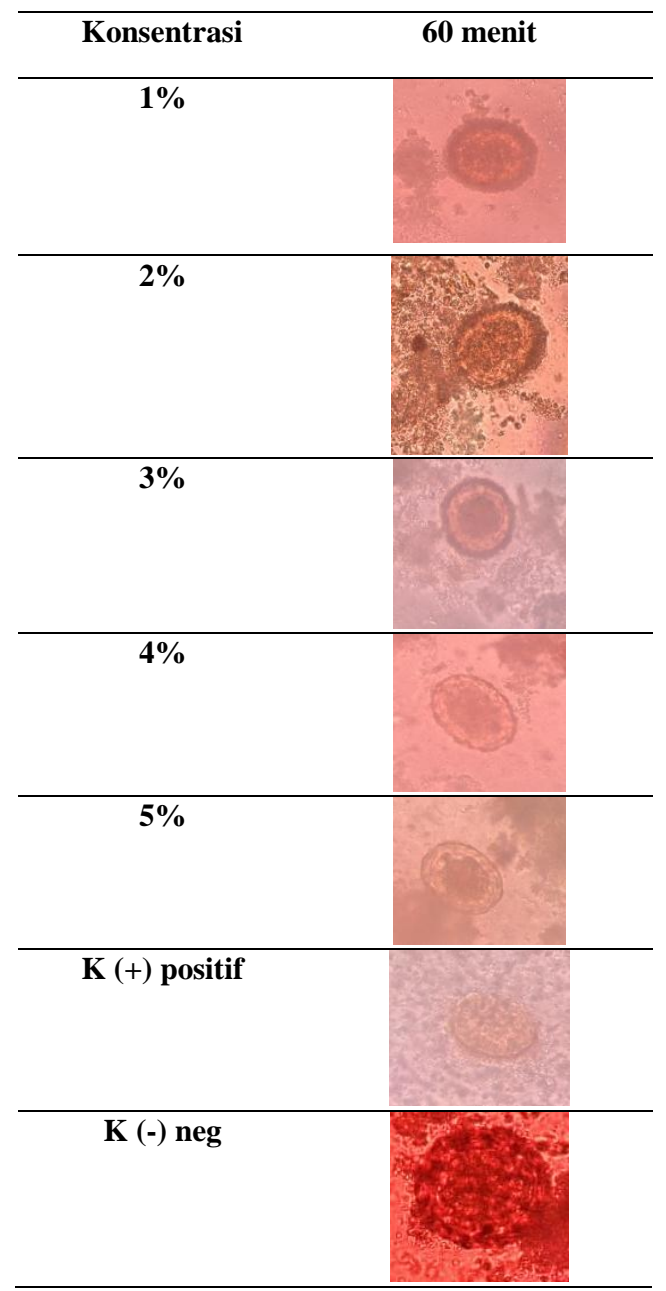

Dari tabel 3.1 uji lisis terhadap telur Ascaris lumbricoides menggunakan getah pepaya, terlihat bahwa pada konsetrasi 5\% lapisan luar mengalami perubahan seperti telur decorticated, begitu juga lapisan dalam (massa telur) terjadi penciutan, sedangkan konsentrasi 1\%-4\% telur tidak mengalami perubahan.Pada kontrol (+) post, jelas telur mengalami perubahan berbeda dengan kontrol (-) neg, telur tetap utuh.

\section{UCAPAN TERIMAKASIH}

Ucapan terimakasih kepada pihak terkait yang telah membantu dan bekerjasama demi kelancaran penelitian ini. 


\section{DAFTAR PUSTAKA}

Andiarsa, D. 2014. Effectivity of papaya seeds againsts Ascaris suum : an in-vitro study. jurnal Vektor Penyakit. volume 8(1): Halaman 21-26.

Ideham, B., dan Pusarawati, S. 2007. Helmintologi Kedokteran. Airlangga University Press. Surabaya

Idris, S, A., dan Fusvita, A. 2017. Identifikasi Telur Nematoda Usus (Soil Transmitted Helmints) Pada Anak Di Tempat Pembuangan Akhir (TPA) Puuwantu. Jurnal Biowallancea. Volume 4(1): Halaman 566-571.

Irianto, K. 2009. Parasitologi: Berbagai Penyakit Yang Mempengaruhi Kesehatan Manusia. Yrama Widya. Bandung.

Irianto, K. 2013. Parasitologi Medis (Medical Parasitology). Alfabeta. Bandung.

Kalma. 2018. Studi Kadar C-Reactive Protein (Crp) Pada Penderita Diabetes Melitus Tipe 2. Jurnal Media Analis Kesehatan. Volume 1(1): Halaman 62-68

Kartini, S. 2016. Kejadian Kecacingan pada Siswa Sekolah Dasar Negeri Kecamatan Rumbai Pesisir. Jurnal Kesehatan Komunitas. Volume 3(2): Halaman 5358.

Pangestu, T., Fitriani, I, N., Ekaputra, F., dan Hermawan, A. 2013. Sweet Papaya Seed Candy" Antibacterial Escherichia Coli Candy With Papaya Seed (Carica Papaya L). Jurnal Pelitan. Volume 8(2): Halaman 156-163.

Pusarawati, S., Ideham, B., Kusmartisnawati., Tantular, I, S., dan Basuki, S. 2014. Atlas Parasitologi Kedokteran. EGC. Jakarta.
Regina, M, P., Halleyantoro, R., dan Bakri, S. 2018. Perbandingan Pemeriksaan Tinja Antara Metode Sedimentasi Biasa Dan Metode Sedimentasi Formolether Dalam Mendeteksi Soil-Transmitted Helminth. Jurnal Kedokteran Diponegoro. Volume 7(2): Halaman 527-537.

Safar, R. 2009. Parasitologi Kedokteran: protozologi, entomologi, dan helmintologi. Yrama Widya. Bandung.

Septiadi, M, G, S., Dwinata, I, M., dan Oka, I, B, M. 2016. Vermisidal dan Ovasidal Getah Biduri (Calotropis Spp.) Terhadap Fasciola Gigantica Secara In Vitro. Jurnal Indonesia Medicus Veterinus. Volume 5(1): Halaman 54-60.

Soedarto. 2016. Buku Ajar Parasitologi Kedokteran. Sagung Seto. Jakarta.

Sonda, K, S., Samsuri., dan Oka, I, B, M. 2018. Vermisidal dan Ovisidal Ekstrak Metanol Biji Pepaya Muda Terhadap Ascaridia galli Secara In-Vitro. Jurnal Indonesia Medicus Veterinus. Volume 7(3): Halaman 295-304.

Supriastuti. 2006. Infeksi soil-transmitted helminth: ascariasis, trichiuriasis dan cacing tambang. Jurnal Universa Medicina. Volume 25(2): Halaman 8493.

Susanto, I., Ismid, I, S., Sjarifuddin., dan Sumgkar, S. 2008. Buku Ajar Parasitologi Kediokteran. Balai Penerbit FKUI. jakarta.

Suryatinah, Y., Andiarsa, D., dan Hairani, B. 2013. Cysteine effect to crude papain proteolytic activity on Ascaridia galli mortality In Vitro. Jurnal Buski. Volume 4(4): Halaman188-191.

Widiastuti, R., Ismiyati., Aini, R. 2015. Pengaruh Pemberian Berbagai Kadar Getah Buah Pepaya ( Carica papaya, $L$ .) Terhadap Jumlah Kumulatif Kematian 
Larva Aedes aegypti. Jurnal Kesmas.

Volume 9(1): Halaman 61-68.

Widodo, H. 2013. Parasitologi Kedokteran.

D-Medika. Jogjakarta.

Yahya, M. 2012. Khasiat Daun Pepaya Untuk

Penderita Kanker. Dunia Sehat. Jakarta. 